\title{
THE EFFECT OF GLAUCOMA FILTRATION SURGERY ON STRUCTURAL AND FUNCTIONAL EYE PARAMETERS IN A SHORT-TERM STUDY
}

\author{
Kristīne Baumane ${ }^{1,2, \#, ~ R e n a ̄ t e ~ R a n k a ~}{ }^{1,3}$, and Guna Laganovska ${ }^{1,2}$ \\ 1 Riga Stradiņš University, Dzirciema iela 16, Riga, LV-1007, LATVIA \\ 2 Department of Ophthalmology, Pauls Stradiṇš Clinical University Hospital, Pilsoṇu iela 13, Riga, LV-1002, LATVIA \\ ${ }^{3}$ Latvian Biomedical Research and Study Centre, Rātsupītes iela 1, Riga, LV-1067, LATVIA \\ \# Corresponding author, baumanek@ml.Iv
}

Communicated by Aija Žileviča

\begin{abstract}
Glaucoma filtration surgery (trabeculectomy) is an effective glaucoma treatment method that provides significant intraocular pressure (IOP) reduction. Indications for this method are in cases where other forms of therapy, like medicines or lasers, have failed, other forms of therapy are not suitable (compliance or side-effects are a problem), in cases where a target pressure is required to prevent clinically significant disease progression that cannot be reached with topical medications and/or laser and in cases that have such advanced glaucoma and high IOP at presentation that other forms of treatment are unlikely to be successful. The aim of this study was to evaluate the effect of glaucoma surgery on the structural and functional eye parameters at different stages of glaucoma. A total of 96 eyes of 96 patients (only one eye from each patient) with different stages of glaucoma (stages 2 to 4) who were undergoing trabeculectomy were recruited. Quadrant retinal nerve fibre layer RNFL) thickness (33 patients), cup/disc vertical and horizontal ratio (36 patients) and MD of visual fields (27 patients) were analysed up to one week before and 1 month after the successful surgery. The results show that the MD value was slightly improved in $50 \%, 85.7 \%$, and $71.4 \%$ of patients with glaucoma stages 2,3 , and 4 , respectively. The mean RNFL of all four optic nerve head quadrants increased slightly after the surgery for patients with glaucoma stage 2; in contrast, a decrease in the mean RNFL values for all four quadrants was observed for patients with glaucoma stage 4. Statistically significant changes in the mean values for the optic nerve horizontal c/d ratio after glaucoma surgery were observed $(\mathrm{p}=0.033)$ in contrast to the vertical $c / d$ values $(\mathrm{p}=0.77)$. In total, improvement of the horizontal and vertical $c / d$ ratio was detected in $61.1 \%$ and $55.6 \%$ of the glaucoma patients, respectively. Although the observed changes were statistically insignificant, the positive influence of glaucoma surgery on the structural and functional eye parameters was more pronounced in moderate stages than in advanced or severe stages of glaucoma.
\end{abstract}

Key words: optic cup/disc ratio, RNFL thickness, trabeculectomy, mean deviation of visual field.

\section{INTRODUCTION}

Glaucoma is one of the leading causes of irreversible blindness worldwide. Nearly 70 million people worldwide suffer from this condition (Flanangan, 1998). Glaucoma is not a single disease but rather a group of ophthalmic diseases with diverse clinical presentation whose common denominator, if left untreated, is progressive retinal ganglion cells (RGCs) degeneration eventually leading to irreversible blindness (Gupta, 2005). Studies have shown that early diagnosis and treatment can delay or prevent disease onset and progression, thus preserving vision in glaucoma patients (Hattenhauer et al., 1998; Heijl et al., 2002; Kass et al., 2002). Structural changes like RNFL thickness changes in glaucoma are often detectable before the functional impairment can be identified using visual field assessment (Sommer et al., 1991), however, the relationship between structure and function may vary according to glaucoma severity. In fact, we know from literature and everyday practice that in the advanced stages of glaucoma, functional tests are more useful than structural ones, mainly to plan a therapeutical strategy. Clinical ophthalmoscopic examination can now be complemented by several technologies that have been developed for the assessment of the optic nerve head and RNFL thickness, including scanning laser polarimetry, scanning laser ophthalmoscopy and ocular coherence 
tomography, which provide images that can be stored and used to track disease progression in individual patients. It has been undoubtedly shown that IOP plays a role in the development of glaucomatous damage and that IOP reduction is therapeutically beneficial in glaucoma. Elevated IOP is regarded as the main risk for glaucomatous optic neuropathy, and numerous treatment modalities have been proposed and used to lower IOP (Grieshaber et al., 2007), including medications, laser treatment and glaucoma surgery. The goal of glaucoma filtration surgery (trabeculectomy) is the same as the goal of medical therapy and laser therapy: to prevent the degradation of visual function by halting the progressive damage to the optic disc caused by either increasing outflow facility or decreasing aqueous production. In most cases, conventional surgical intervention is generally considered when medical and laser therapies fail to achieve the target IOP for a given patient; however, there is evidence that the filtration surgery may be insufficiently effective in advanced stages of glaucoma due to evidence of other risk factors than IOP (Gupta, 2005). We know that progressive RGCs loss continues despite low IOP.

Although the positive impact of the glaucoma filtration surgery on IOP is generally accepted (Anonymous, 2017), the influence of this manipulation on the structural and functional parameters of the eye is still not clear. There are several studies that evaluated long-term results after trabeculectomy (Aydin et al., 2003; Chang et al., 2007; Rebolleda et al., 2007). Raghu and colleagues showed that RNFL thickness increases and cup area decreases for a transient period after glaucoma surgery but reverts back to preoperative values within three months (Raghu et al., 2012). Bertrand with co-authors confirmed in retrospective study that progression of visual field changes continues after trabeculectomy, albeit at a slower rate (Bertrand et al., 2014). Kotecha with colleques concluded that approximately one-third of eyes continued to show progression of glaucoma at five years after trabeculectomy (Kotecha et al., 2009). However, the effect of surgery in different glaucoma stages has not been studied widely. In a previous study (Shiota et al., 2006) glaucoma stages divided in subgroups based on the MD index of visual fields. We used this approach. The aim of this study was to evaluate the short-term effect of glaucoma filtration surgery on structural and functional eye parameters in different stages of glaucoma.

\section{MATERIALS AND METHODS}

In this study, patients with scheduled glaucoma surgery in Pauls Stradiňš Clinical University Hospital, Department of Ophthalmology were enrolled. In total, 96 operated eyes of 96 patients were included in the study: only one eye per patient was operated to exclude infection risk. Surgery was scheduled due to glaucoma progression and inadequate reduction of IOP by medications. Patients $>18$ years of age whose IOP was $>30 \mathrm{mmHg}$ were enrolled. Additional inclusion criteria of patients were the absence of severe intraoperative or postoperative complications and postoperative IOP less than $18 \mathrm{~mm} \mathrm{Hg}$. All patients provided signed consent to participation, and the study was approved by the local ethical committee. The study was conducted in accordance with the Helsinki Declaration.

All patients who met the inclusion criteria and approved their participation in this study were assigned into three groups based on the data available and reliability indices of obtained measurements to analyse the main structural and functional eye (indices) parameters: mean deviation of visual field (MD), RNFL thickness and optic nerve cup/disc ratio (c/d ratio). All parameters were measured up to one week before surgery and one month (30-40 days) after completely successful surgery (post-operation IOP for all patients was $\leq 18 \mathrm{mmHg}$ without medications). IOP data were obtained in the sitting position by the same physician using a Goldmann applanation tonometer.

For MD measurements, 27 patients ( 8 females and 19 males, mean age $67 \pm 10$ ) were involved. MD, the mean difference between the normal sensitivity (corrected for age) and the retinal sensitivity for the subject calculated from all the points tested, was measured by standard automated perimetry (SAP) using a threshold strategy with double bracketing and was performed on an "OCULUS Centerfield" perimeter (OCULUS Optikgeräte GmbH, Germany). Data were analysed by the full-threshold programme 30-2; SITA (Swedish Interactive Thresholds Algorithm) standard 30-2 strategy. All subjects had good visual acuity, were experienced with perimetry and were free of significant cataracts or pupillary miosis. For all included patients, at least five reliable central visual field results were obtained before the study. From analysis were excluded eyes with unreliable visual fields (defined as false negative 33\%, false positive $33 \%$, and fixation losses 20\%). The categorisation into three subgroups of glaucoma was performed by Hodapp's classification based on the MD index of visual fields (Hodapp et al., 1993). In our study stage 2 was defined as early glaucoma with visual field MD index $\leq 6 \mathrm{~dB}$, stage 3 as moderate glaucoma with MD 6-12 dB and stage 3 severe glaucoma with MD worse than $12 \mathrm{~dB}$ (positive ranges for the used device).

For RNFL and for c/d ratio measurements, 33 patients (11 females and 22 males, mean age $68 \pm 8$ ) and 36 patients (13 females and 23 males, mean age $68 \pm 8$ ) were involved, respectively. Optical coherence tomography (OCT) was used to assess the structural properties of optic nerve (vertical and horizontal c/d ratio) and RNFL thickness. RNFL thickness was measured in four quadrants of the optic nerve head (superior, inferior, nasal, and temporal) using the Zeiss Optical Coherence Tomographer Stratus OCT version 4.0.5 (Carl Zeiss Meditec Ophthalmic Systems Inc., Dublin, CA, USA). All scans were obtained by the same experienced operator. Patients were examined after pupillary dilatation to a minimum $5 \mathrm{~mm}$. The imaging lens was positioned $1 \mathrm{~cm}$ from the eye and was adjusted independently until the retina was in focus. The OCT images were analysed using the built-in Stratus OCT Stratus version 4.0.5.; Carl Zeiss Meditec) software. The RNFL thickness was determined at 256 points around a set diameter $(3.4 \mathrm{~mm})$ in the centre of 
the optic disc three times during a single scan; the Fast RNFL programme was used. These values were averaged to yield 12 clock hour thicknesses, four-quadrant thickness and a global average RNFL thickness measurement (360 degree measure). These values were compared against a normative database of age-matched control subjects to derive percentile values. The four percentile values included in the OCT software were the top $5^{\text {th }}$ percentile, top 95 percentile, bottom $5^{\text {th }}$ percentile, and bottom percentile. Vertical and horizontal c/d ratio was obtained with the same device, using fast optic nerve programme. Accuracy of measurement using the OCT method is $8-10$ micrometres.

All glaucoma filtration surgeries were trabeculectomies with a fornix-based conjunctival flap using mitomicin $\mathrm{C}$ as an antifibrotic agent. All surgeries were performed by the same surgeon, using the same surgical technique. Preoperative preparation of patients was performed with the topical anaesthetic Proxyimetacainum $0.5 \%$ and a sub-tenon block using Sol. Lidocaine $2 \%$ mixed with Sol. Bupivacaine 0.5\% 50:50. A partial-thickness corneal traction suture with 7-0 silk was used for eye stabilisation. A fornix-based conjunctival flap was dissected. The sclera was exposed, and haemostasis was achieved by wet-field cautery of the episcleral area before creating the scleral flap. Mitomicin $\mathrm{C}$ (MMC) $0.4 \%$ on 3-4 pieces of sponge was used as an adjuvant to cover a broad area of the superior episclera for 2 minutes. Then the sponges were removed, and residual MMC was washed away with $20-30 \mathrm{ml}$ of balanced salt solution. A partial-thickness scleral flap (4 $\mathrm{mm}$ base and 4 mm height) was created, and MMC $0.4 \%$ was applied for 1 min under the scleral flap. The residual MMC was again washed away with $20-30 \mathrm{ml}$ of balanced salt solution. Paracentesis through the temporal clear cornea was performed. A sclerostomy $(2-2.5 \mathrm{~mm})$ was performed, and peripheral iridectomy was performed using forceps through the sclerostomy. The scleral flap was sutured with 2-4 interrupted 10-0 nylon sutures at the sides of the flap. The conjunctiva and tenons were closed using 10-0 vicryl sutures. The corneal traction suture was removed. The anterior chamber was reinflated with balanced salt solution, and the elevation of the bleb was checked. To check for leaks, $2 \%$ fluorescein solution was used over the bleb surface.

All statistical analyses were performed using GraphPad Software (GraphPad Software Inc., USA). The paired $t$ test was employed to determine the two-tailed $p$ value, and a two-tailed $p$ value less than or equal to 0.05 was considered significant.

\section{RESULTS}

In this study, three different structural and functional eye parameters were analysed in patients with stage 2 (early) glaucoma, stage 3 (moderate) glaucoma, and stage 4 (severe) glaucoma: MD, RNFL, and c/d ratio. After the surgery, all involved patients had satisfying glaucoma surgery results: one month after surgery mean IOP was $12.3 \mathrm{~mm}$ $\mathrm{Hg}$, no significant complications after surgery developed.

First, changes in MD were evaluated in 27 glaucoma patients by comparing the MD values before and after the surgery. The MD value was slightly improved in $50.0 \%$ (3 of 6 ), $85.7 \%$ (6 of 7) and $71.4 \%$ (10 of 14 of patients with glaucoma stages 2, 3, and 4, respectively (Table 1). However, these changes were not statistically significant. In total, a slight reduction in MD of the visual field after surgery was observed in $70.4 \%$ (19 of 27) of glaucoma patients ( $p=$ 0.0916).

Changes in retinal nerve fibre thickness (RNFL) after glaucoma surgery were evaluated by OCT in 33 patients. Patients were measured with the peripapillary Fast RNFL program described above. Measurements were performed for all four quadrants of the optic nerve head: superior, inferior, nasal, and temporal (Table 2).

The data showed that the mean RNFL of all four optic nerve head quadrants increased slightly after surgery for patients with glaucoma stage 2 (9 eyes); the most pronounced change was for the nasal segment (mean difference $=14.4$, $p=0.148)$. In patients with glaucoma stage 3 (17 eyes), the mean RNFL of the superior, inferior and temporal quadrants after the surgery showed a slight increase; in contrast, a decrease in the mean thickness for the nasal quadrant was observed (Table 2). Unfortunately, a decrease in the mean RNFL values for all four quadrants was observed for patients with glaucoma stage 4 (7 eyes). However, these findings, as for the stage 2 and 3 data, were not statistically significant (Table 2).

Next, the optic nerve c/d ratio was analysed in thirty-six patients with different stages of glaucoma (Table 3). Changes in the optic nerve c/d ratio after glaucoma surgery were ana-

MEAN DEVIATION (MD) OF VISUAL FIELD AFTER GLAUCOMA SURGERY

\begin{tabular}{|c|c|c|c|c|c|c|}
\hline \multirow{2}{*}{$\begin{array}{l}\text { Glaucoma } \\
\text { stage }\end{array}$} & \multicolumn{2}{|c|}{$\mathrm{n}$ of eyes } & \multicolumn{4}{|c|}{ Mean MD $(\mathrm{dB}) \pm \mathrm{SD}$} \\
\hline & Total $\mathrm{n}$ & $\begin{array}{c}\mathrm{n}(\%) \text { with } \\
\text { improvement }\end{array}$ & Pre-op & Post-op & m.d. & $p$ value \\
\hline 2 & 6 & $3(50.0)$ & $3.72 \pm 2.08$ & $4.19 \pm 4.22$ & -0.47 & 0.7865 \\
\hline 3 & 7 & $6(85.7)$ & $9.34 \pm 1.8$ & $8.46 \pm 2.36$ & 0.89 & 0.1341 \\
\hline 4 & 14 & $10(71.4)$ & $14.82 \pm 0.29$ & $13.24 \pm 2.75$ & 1.58 & 0.0482 \\
\hline All stages & 27 & $19(70.4)$ & $10.93 \pm 4.79$ & $9.99 \pm 4.75$ & 0.94 & 0.0916 \\
\hline
\end{tabular}

SD, Standard deviation; Pre-op, before surgery; Post-op, after surgery; m.d., mean difference between two means. 
RETINAL NERVE FIBRE THICKNESS (RNFL) AFTER GLAUCOMA SURGERY

\begin{tabular}{|c|c|c|c|c|c|c|c|c|c|c|c|c|c|c|c|c|c|}
\hline \multirow{3}{*}{$\begin{array}{l}\text { Glau- } \\
\text { coma } \\
\text { stage }\end{array}$} & \multirow{3}{*}{$\begin{array}{l}\text { Total } n \\
\text { of eyes }\end{array}$} & \multicolumn{16}{|c|}{ Mean RNFL thickness $(\mu \mathrm{m}) \pm$ SD } \\
\hline & & \multicolumn{4}{|c|}{ RNFL superior } & \multicolumn{4}{|c|}{ RNFL inferior } & \multicolumn{4}{|c|}{ RNFL temporal } & \multicolumn{4}{|c|}{ RNFL nasal } \\
\hline & & Pre-op & Post-op & m.d. & $p$ value & Pre-op & Post-op & m.d. & $p$ value & Pre-op & Post-op & m.d. & $p$ value & Pre-op & Post-op & m.d. & $p$ value \\
\hline 2 & 9 & $\begin{array}{c}76.8 \pm \\
26.3\end{array}$ & $\begin{array}{c}85.4 \pm \\
28.6\end{array}$ & 8.7 & 0.094 & $\begin{array}{c}70.1 \pm \\
27.8\end{array}$ & $\begin{array}{c}75.0 \pm \\
36.8\end{array}$ & 4.9 & 0.478 & $\begin{array}{c}54.7 \pm \\
21.4\end{array}$ & $\begin{array}{c}61.3 \pm \\
23.2\end{array}$ & 6.7 & 0.294 & $\begin{array}{c}45.0 \pm \\
20.0\end{array}$ & $\begin{array}{c}59.4 \pm \\
15.8\end{array}$ & 14.4 & 0.148 \\
\hline 3 & 17 & $\begin{array}{c}45.8 \pm \\
25.6\end{array}$ & $\begin{array}{c}52.9 \pm \\
28.2\end{array}$ & 7.1 & 0.297 & $\begin{array}{c}54.1 \pm \\
27.8\end{array}$ & $\begin{array}{c}56.1 \pm \\
20.2\end{array}$ & 2.1 & 0.76 & $\begin{array}{c}30.2 \pm \\
15.6\end{array}$ & $\begin{array}{c}40.9 \pm \\
20.0\end{array}$ & 10.7 & 0.085 & $\begin{array}{c}47.1 \pm \\
21.1\end{array}$ & $\begin{array}{c}43.1 \pm \\
21.6\end{array}$ & -4.0 & 0.496 \\
\hline 4 & 7 & $\begin{array}{c}49.4 \pm \\
16.5\end{array}$ & $\begin{array}{c}48.3 \pm \\
14.7\end{array}$ & -1.1 & 0.837 & $\begin{array}{c}50.0 \pm \\
11.9\end{array}$ & $\begin{array}{c}36.0 \pm \\
22.0\end{array}$ & -14.0 & 0.094 & $\begin{array}{c}36.0 \pm \\
9.3\end{array}$ & $\begin{array}{c}29.3 \pm \\
6.9\end{array}$ & -6.7 & 0.142 & $\begin{array}{c}49.7 \pm \\
11.1\end{array}$ & $\begin{array}{c}41.3 \pm \\
18.2\end{array}$ & -8.4 & 0.416 \\
\hline $\begin{array}{c}\text { All } \\
\text { stages }\end{array}$ & 33 & $\begin{array}{c}55.0 \pm \\
27.2\end{array}$ & $\begin{array}{c}60.8 \pm \\
29.7\end{array}$ & 5.8 & 0.134 & $\begin{array}{c}57.6 \pm \\
25.9\end{array}$ & $\begin{array}{c}57.0 \pm \\
28.7\end{array}$ & -0.6 & 0.892 & $\begin{array}{c}38.1 \pm \\
19.1\end{array}$ & $\begin{array}{c}44.0 \pm \\
21.9\end{array}$ & 5.9 & 0.114 & $\begin{array}{c}47.1 \pm \\
18.7\end{array}$ & $\begin{array}{c}47.2 \pm \\
20.4\end{array}$ & 0.1 & 0.984 \\
\hline
\end{tabular}

SD, Standard deviation; Pre-op, before surgery; Post-op, after surgery; m.d., mean difference between two means.

Table 3

OPTIC NERVE CUP/DISC (C/D) RATIO AFTER GLAUCOMA SURGERY

\begin{tabular}{|c|c|c|c|c|c|c|c|c|c|c|c|}
\hline \multirow{2}{*}{$\begin{array}{l}\text { Glaucoma } \\
\text { stage }\end{array}$} & \multirow{2}{*}{$\begin{array}{c}\mathrm{n} \text { of } \\
\text { patients }\end{array}$} & \multicolumn{5}{|c|}{ Horizontal c/d ratio } & \multicolumn{5}{|c|}{ Vertical c/d ratio } \\
\hline & & Pre-op & Post-op & $\begin{array}{l}\text { Average } \\
\text { decrease }\end{array}$ & $p$ value & $\begin{array}{c}\mathrm{n}(\%) \text { with } \\
\text { decrease }\end{array}$ & Pre-op & Post-op & $\begin{array}{l}\text { Average } \\
\text { decrease }\end{array}$ & $p$ value & $\begin{array}{c}\text { n (\%) with } \\
\text { decrease }\end{array}$ \\
\hline 2 & 9 & $0.634 \pm 0.19$ & $0.58 \pm 0.2$ & 0.05 & 0.09 & $7(77.8)$ & $0.67 \pm 0.18$ & $0.67 \pm 0.17$ & 0.001 & 0.97 & $5(55.6)$ \\
\hline 3 & 19 & $0.90 \pm 0.06$ & $0.89 \pm 0.12$ & 0.02 & 0.40 & $9(47.4)$ & $0.88 \pm 0.8$ & $0.88 \pm 0.06$ & 0.001 & 0.98 & $12(63.2)$ \\
\hline 4 & 8 & $0.94 \pm 0.04$ & $0.87 \pm 0.18$ & 0.07 & 0.24 & $6(75.0)$ & $0.91 \pm 0.06$ & $0.93 \pm 0.05$ & -0.02 & 0.43 & $3(37.5)$ \\
\hline All stages & 36 & $0.84 \pm 0.16$ & $0.81 \pm 0.2$ & 0.04 & 0.03 & $22(61.1)$ & $0.84 \pm 0.15$ & $0.84 \pm 0.14$ & -0.004 & 0.77 & $20(55.6)$ \\
\hline
\end{tabular}

Pre-op, before surgery; Post-op, after surgery.

lysed in all patients. Both the horizontal and vertical c/d ratio were measured, and any decrease was considered an improvement. In total, improvement of the horizontal and vertical c/d ratio was detected in $61.1 \%$ and $55.6 \%$ of the glaucoma patients, respectively. The average decrease was 0.04 for the horizontal c/d ratio and -0.004 for the vertical c/d ratio (Table 3 ). Improvement of c/d ratio after glaucoma surgery was observed in 31 of 36 patients (86.1\%). Importantly, the proportion of patients with improvement in the c/d ratio did not statistically differ among all three glaucoma stages studied $(p>0.05)$. However, statistically significant changes in the mean values for the optic nerve horizontal c/d ratio after glaucoma surgery were observed ( $p=$ $0.033)$, in contrast to the vertical $\mathrm{c} / \mathrm{d}$ values $(p=0.77)$ (Table 3 ).

\section{DISCUSSION}

Glaucoma is now widely accepted to be a progressive optic neuropathy (Weinreb et al., 2004) and has been characterised as a continuum involving structural and functional changes throughout the course of chronic disease (Weinreb et al., 2004); untreated, the condition eventually leads to irreversible blindness. Glaucoma trials provide conclusive evidence confirming that reduction in IOP lowers the risk of progression of optic neuropathy. Each higher (or lower) millimetre of mercury of IOP on follow-up was associated with an approximate 10\% increase (or decrease) in risk of progression (Leske et al., 2003). The goal of glaucoma filtration surgery, which is the most common non-laser surgical procedure, is the same as the goal of medical therapy or laser therapy: to lower the IOP in affected patients and thus to stabilise vision and prevent any further loss of the visual field. Unfortunately, the surgery does not restore any visual field already lost (Lamping et al., 1986). However, some improvements in visual function and structural parameters have been observed (Aydin et al., 2003; Chang et al., 2007; Raghu et al., 2012). Raghu with colleagues noted shortterm fluctuations in RNFL thickness which temporarily increased but the values reverted to normal within three months. Reasons for growth of thickness could be explained as postoperative oedema. Examination of the optic disk, retinal nerve fibre layer, and visual function are essential both for disease staging within the continuum and for monitoring the rate of progression. However, little is known about possible changes in these parameters shortly after successful glaucoma surgery and effective IOP lowering. Thus, a possible improvement in structural and functional properties of the eye after the fornix-based conjunctival flap trabeculectomy was evaluated in this study. Evaluation of short-term changes in RNFL thickness, cup/disc ratio and MD of visual field postoperatively following glaucoma filtration surgery may improve management of glaucoma process. In case of worsening of parameters additional medical therapy must be added despite the low IOP. 
The overall results of this study showed that glaucoma surgery was successful in all involved patients, and the IOPlowering effect was good: one month after the glaucoma operation, the mean IOP was $12.3 \mathrm{~mm} \mathrm{Hg}$. Apparent improvement in the MD of the visual field was observed in a large proportion of our patients: positive changes were documented in 19 of 27 patients $(70.4 \%)$ one month after the surgery. There is a direct relationship between MD value and retinal ganglion cell loss (Bengtsson et al., 2008). Thus, although the observed changes were not statistically significant, it could nonetheless be assumed that the operation slowed the rate of disease progression and kept patients close to stability even in cases of moderate or advanced damage.

Conflicting results have been reported regarding improvement in the postoperative RNFL thickness. Several studies have reported a significant change in RNFL thickness following IOP reduction (Aydin et al., 2003; Sarkar et al., 2014). Similarly, the study of Chang et al. found a significant increase in RNFL, but with no correlation with IOP (Chang et al., 2007). The study of Raghu et al. showed a significant increase in average and inferior RNFL thickness only one week after surgery; the values reverted to preoperative values at three months postoperatively (Raghu et al., 2012). In contrast, the studies of Rebolleda et al. and Topouzis et al. did not find changes in any significant parameter 6 and 8 months after surgery (Rebolleda et al. 2007; Topouzis et al., 1999). Our study showed that the RNFL thickness of the optic nerve head increased slightly one month after the surgery, resulting in successful IOP reduction in patients with glaucoma stage 2 and 3; however, these changes were not statistically significant. No positive changes were observed in patients with severe disease.

Regarding possible changes in the c/d ratio after successful surgery, experimental studies have shown that reversal of cupping is more likely in the earlier stages of glaucoma (Shirakashi et al., 1991; Coleman et al., 1999). In this study, improvement in the horizontal and vertical c/d ratio was detected in $61.1 \%$ and $55.6 \%$ of glaucoma patients, respectively, one month after surgery. However, again, these changes were not statistically significant for either severe or moderate disease.

With the new studies, which all highlight the importance of pursuing aggressive IOP reduction, and considering that many people are living longer than ever before, many patients with glaucoma will undoubtedly be referred for surgical intervention. In some cases, glaucoma surgery is recommended earlier, for example, in patients with normaltension glaucoma, in patients who demonstrate a clear pattern of non-compliance, or in patients who will lose significant visual function unless immediate intervention is undertaken. This study provides evidence that glaucoma surgery not only results in lower IOP, which is crucial for the prevention of optic neuropathy progression, but also could slightly improve structural and functional eye parameters. Although statistically insignificant, some positive improvements were observed, mainly in patients with glaucoma stages 2 and 3; in contrast, few if any patients with severe glaucoma (stage four) experienced noticeable changes after surgery. Thus, surgical intervention should be advised in all cases of insufficient IOP reduction, despite maximal medical therapy, and with confirmed functional loss as early as possible.

In conclusion, in cases of successful glaucoma surgery where the IOP-lowering effect is good, some improvement in structural and functional properties of the eye can be expected, especially in non-advanced stages of glaucoma stages.

\section{REFERENCES}

Anonymous (2017). Terminology and Guidelines for Glaucoma. $4^{\text {th }}$ edn. ISBN: 978-88-98320-05-9. Available at:

http://www.eugs.org/eng/EGS_guidelines.asp (accessed 22 February 2017).

Aydin, A., Wollstein, G., Price, L. L., Fujimoto, J. G., Schuman, J. S. (2003). Optical coherence tomography assessment of retinal nerve fiber layer thickness changes after glaucoma surgery. Ophthalmology, 110, 1506-1511.

Bengtsson, B., Heijl, A. (2008). A visual field index for calculation of glaucoma rate of progression. Amer. J. Ophthalmol., 145, 343-353.

Bertrand, V., Fieuws, S., Stalmans, I., Zeyen, T. (2014). Rates of visual field loss before and after trabeculectomy. Acta Ophthalmologica, 92, 116-120.

Chang, P. T., Sekhon, N., Budenz, D. L., Feuer, W. J., Park, P. W., Anderson, D. R.(2007). Effect of lowering intraocular pressure on optical coherence tomography measurement of peripapillary retinal nerve fiber layer thickness. Ophthalmology, 114, 2252-2258.

Coleman, A. L., Quigley, H. A., Vitale, S., Dunkelberger, G. (1999). Displacement of the optic nerve head by acute changes in intraocular pressure in monkey eyes. Ophthalmology, 98, 35-40.

Flanangan, J. G. (1998). Glaucoma update: Epidemiology and new approaches to medial management. Ophthalmic Physiol. Opt., 18, 126-132.

Grieshaber, M. C., Flammer, J. (2007). Fundamental sciences in glaucoma. Introduction. Surv. Ophthalmol., 52 (suppl. 2), 99-100.

Gupta, D. (2005). Glaucoma Diagnosis and Management. Lippincott Williams \& Wilkins,Philadelphia, pp. 273-274.

Hattenhauer, M. G., Johnson, D. H., Ing, H. H., Herman, D. C., Hodge, D. O., Yawn, B. P., Butterfield, L. C., Gray, D. T. (1998). The probability of blindness from open-angle glaucoma. Ophthalmology, 105, 2099-2104.

Heijl, A., Leske, M. C., Bengtsson, B., Hyman L, Bengtsson B, Hussein M; Early Manifest Glaucoma Trial Group. (2002). Reduction of intraocular pressure and glaucoma progression: Results from Early Manifest Glaucoma Trial. Arch. Ophthalmol., 120, 1268-1279.

Hodapp, E., Parrish, R. K., Anderson, D. R. (1993). Clinical Decisions in Glaucoma. Mosby-Year Book, St. Louis, 204 pp.; see pp. 84-125.

Kass, M. A., Heuer, D. K., Higginbotham, E. J., Johnson, C. A., Keltner, J. L., Miller, J. P., Parrish, R. K. 2nd, Wilson, M. R., Gordon, M. O. (2002). The ocular hypertension treatment study: A randomized trial determines that optical ocular hypotensive medication delays or prevents the onset of primary open-angle glaucoma. Arch. Ophthalmol., 120, 701-713.

Kim, T.-W., Park, U.-C., Park, K., H.., Kim, D., M. (2007). Ability of Stratus OCT to identify localized retinal nerve fiber layer defects in patients with normal standard automated perimetry results, Invest. Ophthalmol. Vis. Sci. 48 (4), 1635-1641.

Kotecha, A., Spratt, A., Bunce, C., Garway-Heath, D. F., Khaw, P. T., Viswanathan, A., More Flow Study Group. (2009). Optic disc and visual field changes after trabeculectomy. Invest. Ophthalmol. Vis. Sci., 50, 4693-4699. 
Lamping, K. A., Bellows, A. R., Hutchinson, B. T., Afran, S. I. (1986). Long-term evaluation of initial filtration surgery. Ophthalmology, 93, 91-101.

Leske, M., C., Heijl, A., Hussein, M., Bengtsson, B., Hyman, L., Komaroff, E.; Early Manifest Glaucoma Trial Group. (2003). Factors for glaucoma progression and the effect of treatment. Arch. Ophthalmol., 121, 48-56.

Mills, R., P., Budenz, D. L., Lee, P. P., Noecker, R. J., Walt, J. G., Siegartel, L. R., Evans, S. J., Doyle, J. J.(2006). Categorizing the stage of glaucoma from pre-diagnosis to end-stage disease. Amer. J. Ophthalmol., 141, 24-30.

Raghu, N., Pandav, S.. S., Kaushik, S., Ichhpujani, P., Gupta, A. (2012). Effect of trabeculectomy on RNFL thickness and optic disc parameters using optical coherence tomography. Eye, 26, 1131-1137.

Rebolleda, G., Muñoz-Negrete, F., Noval, S. (2007). Evaluation of changes in peripapillary nerve fiber layer thickness after deep scleretomy with optical coherence tomography. Ophthalmology, 114, 488-493.

Received 7 November 2016

Accepted in the final form 20 February 2017
Sarkar, K., C, Das, P., Pal, R., Shaw, C. (2014). Optical coherence tomographic assessment of retinal nerve fiber layer thickness changes before and after glaucoma filtration surgery. Oman J. Ophthalmol., 7, 3-8.

Shirakashi, M., Nanbam K., Iwata, K. (1991). Changes in reversal of cupping in experimental glaucoma. Ophthalmology, 99, 1104-1110.

Sihota, R., Sony P., Gupta V., Dada, T., Singh, R. (2006). Diagnostic capability of optical coherence tomography in evaluating the degree of glaucomatous retinal nerve fiber damage. Invest. Ophthalmol. Vis Sci., 47, 2006-2010.

Sommer, A., Katz, J., Quigley, H. A., Miller, N. R., Robin, A. L., Richter, R. C., Witt, K. A. (1991). Clinically detectable nerve fiber atrophy precedes the onset of glaucomatous field loss. Arch. Ophthalmol., 109, 77-83.

Topouzis, F., Peng, F., Kotas-Neumann, R., Garcia, R, Sanguinet, J, Yu, F, Coleman, A. L. (1999). Longitudinal changes in optic disc topography of adult patients after trabeculectomy. Ophthalmology, 106, 1147-1151.

Weinreb, R. N., Friedman, D. S., Fechtner, R. D., Cioffi, G. A., Coleman, A. L., Girkin, C. A., Liebmann, J. M., Singh, K., Wilson, M. R., Wilson, R., Kannel, W. B. (2004). Risk assessment in the management of patients with ocular hypertension. Amer. J. Ophthalmol, 138, 458-467.

Weinreb, R. N., Khaw, P. T. (2004). Primary open-angle glaucoma. Lancet, 363, 1711-1720.

\section{ANTIGLAUKOMATOZAS OPERĀCIJAS IETEKME UZ ACS STRUKTURĀLAJIEM UN FUNKCIONĀLAJIEM PARAMETRIEM İSTERMIN,A PĒTİJUMĀ}

Darba mērkis bija noteikt antiglaukomatozas operācijas ietekmi uz acs strukturālajiem un funkcionālajiem parametriem pacientiem dažādās glaukomas stadijās vienu mēnesi pēc operācijas. Pētījumā tika iekḷautas 96 glaukomas pacientu 96 acis (2.-3. glaukomas stadijā), kurām tika veikta antiglaukomatoza operācija - trabekulektomija. Pirms operācijas un vienu mēnesi pēc operācijas 33 pacientiem tika izmērīts tîklenes nervu šķiedru slāņa biezums 4 kvadrantos, 36 pacientiem — horizontālā un vertikālā redzes nerva / ekskavācijas attiecība, kā arī 27 pacientiem noteikta redzes lauka vidējā novirze. Redzes lauka vidējā novirze nedaudz uzlabojās 50,0\%, 85,7\% un 71,4\% pacientiem attiecīgi 2., 3. un 4. glaukomas stadijās. Vidējais tīklenes nervu šḳiedru slāṇa biezums visos četros redzes nerva diska kvadrantos nedaudz uzlabojās pēc glaukomas operācijas 2. stadijas pacientiem, bet 4. glaukomas stadijas pacientiem tika konstatēts, ka tas samazinās visos kvadrantos. Pēc glaukomas operācijas statistiski ticami izmainījās redzes nerva horizontālā diska / ekskavācijas attiecība $(p=0.033)$, bet ne vertikālā diska/ekskavācijas attiecîba $(p=0.77)$. Procentuāli kopumā horizontālās un vertikālās diska / ekskavācijas attiecības uzlabošanās attiecīgi tika konstatētas $61,1 \%$ un 55,6\%. Lai arī pētījumā iegūtie rezultāti nav statistiski ticami, tomēr tika konstatēta pozitīva antiglaukomatozas operācijas ietekme uz acs strukturālajiem un funkcionālajiem parametriem 2. glaukomas stadijas gadījumos vairāk nekā 3. un 4. stadijas glaukomas gadijjumos. 